\title{
Late Compartments of Amyloid Precursor Protein Transport in SY5Y Cells Are Involved in $\beta$-Amyloid Secretion
}

\author{
Gisela C. Peraus, ${ }^{1}$ Colin L. Masters, ${ }^{2}$ and Konrad Beyreuther ${ }^{1}$ \\ ${ }^{1}$ Center for Molecular Biology Heidelberg, The University of Heidelberg, D-69120 Heidelberg, Germany, and '2Department \\ of Pathology, The University of Melbourne, Parkville, Victoria 3052, Australia
}

Amyloid plaques, composed mainly of the 39-43 amino acid $\beta A 4$ peptide, are a characteristic feature of Alzheimer's disease. Generation of $\beta \mathrm{A} 4$ by proteolytic processing of the amyloid precursor protein (APP) is thought to occur in a pathway that includes the activity of two as yet unknown proteases, with $\beta$-secretase cleaving at the $\mathrm{N}$ terminus and $\gamma$-secretase releasing the $C$ terminus of $\beta A 4$. Inhibition studies and the finding that cell surface APP can serve as a direct precursor of $\beta A 4$ suggest that the endosomal/lysosomal compartment is involved in the proteolysis of APP into $\beta A 4$.

In this study we targeted APP695 chimeric proteins directly into the endosomal/lysosomal compartment. This decreased the amount of released $\beta \mathrm{A} 4$, while the generation of the $\beta \mathrm{A} 4 \mathrm{~N}$ terminus continued. APP695 proteins were constructed also, which carried sorting signals responsible for recycling between the trans-Golgi network (TGN) and the cell surface. These proteins were processed into secreted $\beta A 4$ at even higher levels than wild-type APP695. Moreover, retention of APP695 proteins in the endoplasmic reticulum led to neither $\beta A 4$ secretion nor to processing by $\beta$-secretase in human SH-SY5Y neuroblastoma cells.

These data suggest that a $\beta$-cleavage activity resides in a late endosomal compartment and that a $\gamma$-cleavage occurs in early endosomes, resulting in the generation of $\beta A 4$ peptides with the majority ending at residue 40 .

Key words: Alzheimer's disease; APP processing; $\beta$-amyloid; chimeric proteins; endosomal/lysosomal compartment; transport
A major histopathological marker of Alzheimer's disease is the presence of cerebral amyloid plaques, which are composed mainly of the insoluble $4 \mathrm{kDa} \beta \mathrm{A} 4$ peptide (Glenner and Wong, 1984; Masters et al., 1985). $\beta$ A4 derives from the larger amyloid precursor protein (APP) by the activity of two proteases termed $\beta$ and $\gamma$-secretase (Kang et al., 1987). During its transport through the constitutive secretory pathway a proportion of APP is secreted by cleavage within the $\beta \mathrm{A} 4$ sequence, thereby precluding the generation of $\beta$ A4 (Weidemann et al., 1989; Esch et al., 1990).

In an alternative pathway involving the endosomal/lysosomal system, APP is processed into C-terminal fragments that contain the entire $\beta A 4$ domain (Cole et al., 1989; Golde et al., 1992; Haass et al., 1992a). Although indicating the potential importance of this part in amyloidogenic processing, these fragments also have been proposed to be intermediates of the final degradation of APP in lysosomes (Haass and Selkoe, 1993). However, various agents that interfere with $\mathrm{pH}$ gradients reduce the generation of $\beta \mathrm{A} 4$ drasti-

Received March 14, 1997; revised July 7, 1997; accepted July 24, 1997.

This work was supported by the Deutsche Forschungsgemeinschaft through SFB 317, Bundesministeriam fur Bildang, Wissenschaft, Forschang und Technologie Grant 0310666, Erna Struckmann Foundation, and the Fonds der Chemischen Industrie, Germany. We thank Professor Regina Pohlmann (Zentrum für Biochemie und Molekulare Zellbiologie, Georg-August-Universität, Göttingen, Germany) for providing the cDNA of the cytoplasmic tail of the CD-MPR. We thank Dr. Ursula Mönning (Schering AG, Berlin, Germany); Dr. Gerd Multhaup, Dr. Nobuo Ida, and Professor Bernhard Dobberstein (Center for Molecular Biology Heidelberg, Heidelberg, Germany); Professor Bernhard Hoflack (European Molecular Biology Laboratory, Heidelberg, Germany); Professor George Banting (Department of Biochemistry, Bristol, UK); and the Developmental Studies Hybridoma Bank (University of Iowa, IA) for providing antibodies anti-Fd-APP, anti- $\beta$ A4, anti-sec61, anti-CI-MPR, anti-TGN38, and anti-hLAMP-1, respectively. We thank Krzysztof Paliga for help with cloning work and Dirk Beher and Dr. Pentti Tienari for helpful discussions.

Correspondence should be addressed to Dr. Gisela C. Peraus at the above address.

Copyright (C) 1997 Society for Neuroscience $0270-6474 / 97 / 177714-11 \$ 05.00 / 0$ cally (Haass et al., 1992b; Shoji et al., 1992), supporting the idea that an acidic compartment is necessary for $\beta \mathrm{A} 4$ formation.

To analyze the involvement of the endosomal/lysosomal system in the processing of APP695 into $\beta$ A4, we created APP 695 chimeras by exchanging the cytoplasmic domain of APP695 with that of the human lysosomal-associated membrane protein-1 (hLAMP-1) and the human cation-dependent mannose 6-phosphate receptor (CDMPR). These APP hybrids were expected to follow the transport of hLAMP-1 and CD-MPR, respectively. The majority of the hLAMP-1 has been shown to be transported directly from the trans-Golgi network (TGN) to lysosomes (Höning et al., 1996). The CD-MPR is sorted from the TGN to the prelysosomal compartment and either returns to the TGN or is transported to the plasma membrane. Importantly, and distinct from hLAMP-1, the receptor is not transported to lysosomes (Rohrer et al., 1995).

To analyze whether the secretory pathway plays a role in the amyloidogenic processing of APP695, we constructed an APP695 hybrid containing the C-terminal sorting signal of rat TGN38. This protein has been shown to recycle between the TGN and the cell surface, but at steady state it is located predominantly in the TGN (Reaves et al., 1993). Finally, an APP695 chimera was created bearing a di-lysine-based endoplasmic reticulum (ER) retention signal at its $C$ terminus (Cosson and Letourneur, 1994).

Our results suggest a model in which a $\beta$-secretase occurs within a prelysosomal compartment. A $\gamma$-cleavage activity might be found in early endosomes and leads to the secretion of $\beta \mathrm{A} 4$, which we identified mainly to correspond to $\beta A 4_{1-40}$. Lysosomes seem not to be required for the processing of APP695 into $\beta A 4$.

\section{MATERIALS AND METHODS}

Plasmid constructions. The cDNA encoding the cytoplasmic domain of the human CD-MPR and of human LAMP-1 was obtained by PCR amplification, using LAP-MPR46 pBELCe (Pohlmann et al., 1987) as a 
template and oligonucleotide synthesis, respectively. The cDNA fragments were cloned into the plasmid cmv II APP695 [modified (Weidemann et al., 1989)], using new cloning sites $R s a \mathrm{I}$ and $B s p \mathrm{I}$, respectively, which have been created by PCR in the APP cDNA region encoding the last amino acid residues of the transmembrane domain just before the lysine triplet. The regions created by PCR were sequenced by the dideoxy chain termination method, and the APP chimeric constructs were cloned via pBluescript $\mathrm{SK}^{+}$(Stratagene, GmbH, Heidelberg, Germany) into the pCEP4 vector (Invitrogen/ITC Biotechnology, GmbH, Heidelberg, Germany). Each construct was c-myc-tagged, using the pSP65 N-tag APP695 vector (Simons et al., 1995), which contains the c-myc sequence (EQKLISEEDL) to the APP N terminus; the constructs were termed $A P P-M P R$ and $A P P-L A M P$, respectively. $A P P w t$ was constructed by exchanging the $A P P-M P R$ cDNA fragment, which encodes the MPR cytoplasmic domain, with the corresponding cDNA of pSP65 N-tag APP695. For the construction of $A P P-K K L N$ and $A P P-S D Y Q R L$, two oligonucleotides were synthesized encoding the last six $\mathrm{C}$-terminal amino acid residues of APP695, followed by the signal sequences KKLN or SDYQRL, respectively. Corresponding PCR-generated DNA fragments using the plasmid cmv II APP695 as a template were cloned into the plasmid $\mathrm{cmv}$ II APP695 after the c-myc sequence was introduced to the $\mathrm{N}$ terminus of APP. The DNA fragments generated by PCR were sequenced, and the cDNA fragments encoding APP-KKLN and APP-SDYQRL were cloned into the pCEP4 expression vector.

DNA transfection and expression in SH-SY5Y cells. The human neuroblastoma cell line SH-SY5Y was maintained as described (Ross et al., 1983). Semiconfluent cells were transfected with $2 \mu \mathrm{g}$ of plasmid DNA per 60-mm-diameter culture dish, using lipofectin as described by the producer (Life Technologies/BRL, Eggenstein, Germany). After the transfected cells of one dish were pooled, the expression was examined by immunoprecipitation with Fd-APP antiserum (Weidemann et al., 1989) and immunoblotting with mouse monoclonal antibody $22 \mathrm{C} 11$, which recognizes the APP N terminus (Hilbich et al., 1993), and mouse monoclonal anti-c-myc antibody (clone 9E10) (ZENECA/ICI, Frankfurt, Germany) (Evan et al., 1985), using the ECL detection kit (Amersham, Braunschweig, Germany).

Metabolic labeling and immunoprecipitation. Stably transfected SY5Y cells of a $100 \mathrm{~mm}$ culture dish were treated with $3 \mathrm{ml}$ of minimum essential medium (MEM) lacking methionine (Sigma, München, Germany), supplemented with $300 \mu \mathrm{Ci}$ of $\left[{ }^{35} \mathrm{~S}\right]$ methionine (Amersham, Braunschweig, Germany) for $3 \mathrm{hr}$ for the detection of APP, A4CT, and $\mathrm{p} 3 \mathrm{CT}$, and with MEM supplemented additionally with $10 \%(\mathrm{v} / \mathrm{v})$ dialyzed fetal calf serum (FCS) for $16 \mathrm{hr}$ for the detection of $\beta \mathrm{A} 4$ and $\mathrm{p} 3$.

For pulse chase analysis, cells were radiolabeled for 8 min, using MEM lacking methionine and supplemented with $150 \mu \mathrm{Ci}$ per dish. The chases were performed with DMEM (Sigma) supplemented with $10 \%(\mathrm{v} / \mathrm{v})$ FCS and $1 \mathrm{~mm}$ L-methionine for various periods of time.

The cells were harvested and lysed in lysis buffer $(50 \mathrm{~mm}$ Tris/ $\mathrm{HCl}, \mathrm{pH}$ 7.5, $150 \mathrm{~mm} \mathrm{NaCl}, 1 \% \mathrm{NP} 40,1 \%$ Triton X-100, and $2 \mathrm{~mm}$ EDTA) supplemented with $2 \mathrm{~mm}$ phenylmethylsulfonyl fluoride and $10 \mu \mathrm{g} / \mathrm{ml}$ leupeptin. The 10,000 gm supernatants were used for immunoprecipitation with mAb 4G8 raised against amino acids 17-24 of $\beta$ A4 (Kim et al., $1988)$ and $\mathrm{mAb}$ WO2 (anti- $\beta \mathrm{A} 4_{1-16}$ ) (Ida et al., 1996). For the detection of $\beta \mathrm{A} 4$ and $\mathrm{p} 3$ in the conditioned media, rabbit polyclonal antibodies raised against human $\beta$ A4 synthetic peptide 1-40 (Simons et al., 1996) were used. For separation of $\beta \mathrm{A} 4_{1-40}$ versus $\beta \mathrm{A} 4_{1-42}$, the conditioned media were treated with mAb G2-10 (specific for $\beta A 4_{1-40}$ ) and G2-11 (specific for $\beta \mathrm{A} 4_{1-42}$ ) (Ida et al., 1996). Samples were separated by SDS-PAGE on $7 \%$ gels (APP) or $10-20 \%$ Tris-Tricine gradient gels (Schagger and von Jagow, 1987) ( $\beta$ A4, p3, and C-terminal fragments) Autoradiography with x-ray films (Kodak/Sigma, München, Germany) or phosphorimaging (Fuji Bas 1000) was performed.

Cell surface biotinylation. Stably transfected SY5Y cells of $100 \mathrm{~mm}$ culture dishes were cell surface-biotinylated, using sulfosuccinimidobiotin (sulfo-NHS-biotin, Pierce/Bender \& Hobein, Heidelberg, Germany) as described (Usami et al., 1993). Cells were harvested and lysed. Biotinylated proteins were precipitated with polyclonal goat anti-biotin antiserum (Pierce/Bender \& Hobein) and protein G-agarose. Immunoprecipitates were separated by SDS-PAGE and transferred to nitrocellulose. Biotinylated APP was detected with mAb $22 \mathrm{C} 11$ by the ECL detection kit.

Immunofluorescence and confocal microscopy. Stably transfected SY5Y cells were plated onto glass coverslips $48 \mathrm{hr}$ before use. Cells were fixed and permeabilized by incubation in methanol at $-20^{\circ} \mathrm{C}$ for $5 \mathrm{~min}$. The coverslips were incubated in PBS/10\% goat normal serum (GNS) for 20 min, followed by a PBS wash and incubation with primary antibody in $\mathrm{PBS} / 2 \%$ GNS for $1 \mathrm{hr}$ at room temperature. For the detection of the transfected APP proteins, mAb 9E10 or rabbit polyclonal anti-c-myc antiserum (A14, Santa Cruz Biotechnology, Heidelberg, Germany) recognizing the same epitope as mAb 9E10 was used. Mouse monoclonal anti-hLAMP-1 antibody H4A3 was obtained from the Developmental Studies Hybridoma Bank (DSHB, Baltimore, MD) (Chen et al., 1985). The CI-MPR was detected with a rabbit polyclonal antiserum raised against the $300 \mathrm{kDa}$ MPR kindly provided by Professor Bernhard Hoflack (European Molecular Biology Laboratory, Heidelberg, Germany) (Meresse and Hoflack, 1993). Rabbit polyclonal anti-human homolog of rat TGN38 (hum TGN46) (GB1) was a gift of Professor George Banting (Bristol, UK) (Ponnambalam et al., 1996). Sec61 was detected by a rabbit polyclonal antiserum raised against a synthetic peptide (PGPTPSGTN) to the sec61 $\beta \mathrm{N}$ terminus of dog (Görlich and Rapoport, 1993). The secondary antibodies were goat anti-mouse or goat anti-rabbit conjugated to DTAF (dichlorotriazinyl aminofluorescein) or LRSC (lissamine-rhodamine; Dianova, Hamburg, Germany). The cells were incubated at room temperature with secondary antibodies for 30-45 min, washed, and mounted in polyvinyl alcohol. Confocal microscopy was performed on a Leica microscope with a $63 \times 1.4$ oil immersion objective.

\section{RESULTS}

\section{Detection of the chimeric proteins APP-LAMP and APP-MPR}

We constructed two chimeric APP proteins by replacing the cytoplasmic domain of APP695 (APPwt) (47 aa) with those of hLAMP-1 (11 aa) and CD-MPR (67 aa), termed APP-LAMP and APP-MPR (Fig. 1a). These proteins are expected to follow the intracellular transport of hLAMP-1 and CD-MPR, respectively, because the sorting signals required for trafficking into the endosomal/lysosomal system are localized in the cytoplasmic domain of the corresponding protein (Johnson and Kornfeld, 1992; Guarnieri et al., 1993). For specific detection the APP hybrid proteins were $\mathrm{N}$-terminally tagged with a c-myc epitope.

Stably transfected SH-SY5Y cell lines were established, and the expression of the chimeric APP695 proteins was examined by immunoprecipitation with Fd-APP antiserum, followed by immunoblotting with mAb 22C11 (anti-Fd-APP) or mAb 9E10 (antic-myc). The results are presented in Figure $1 b, c$. The bands that represent APP695sec are indicative for the expression of the chimeric proteins. In contrast, the bands corresponding to APP751/770sec are products of the endogenous APP gene expressed by the SY5Y cells, as shown for cells stably transfected with pCEP4 alone. This result was confirmed by detection with $\mathrm{mAb} 9 \mathrm{E} 10$.

\section{APP-LAMP and APP-MPR were detected mainly in the predicted organelles}

To study the subcellular localization of the chimeric proteins, we performed immunofluorescence confocal microscopy. SY5Y cells stably expressing APP-LAMP were double-stained with c-myc antiserum (Fig. 2a) and monoclonal anti-hLAMP-1 antibodies visualizing endogenous hLAMP-1 (Fig. $2 b$ ). As the arrows indicate, APP-LAMP was found to some extent in the same vesicles as endogenous hLAMP-1. SY5Y cells stably transfected with the APPwt construct and double-stained with the same antibodies showed an overlapping immunoreactivity of APPwt and hLAMP-1 mainly in a perinuclear region (Fig. $2 c, d$ ). This is probably attributable to the presence of the proteins in the biosynthetic pathway.

Because the signal observed from the APP-LAMP stably transfected cells was always very weak, we assumed that APP-LAMP might be degraded very rapidly in the lysosomes. To test this hypothesis, we treated the cells with the lysosomal protease inhibitor leupeptin, followed by an incubation with the same 
a
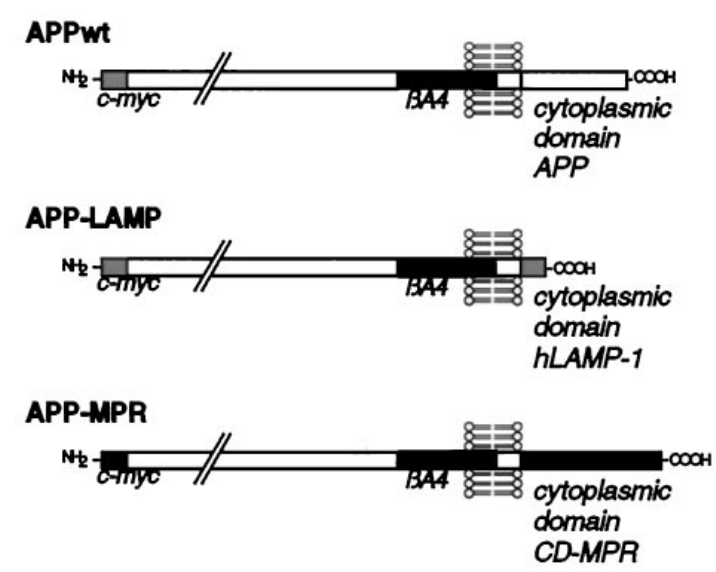

b

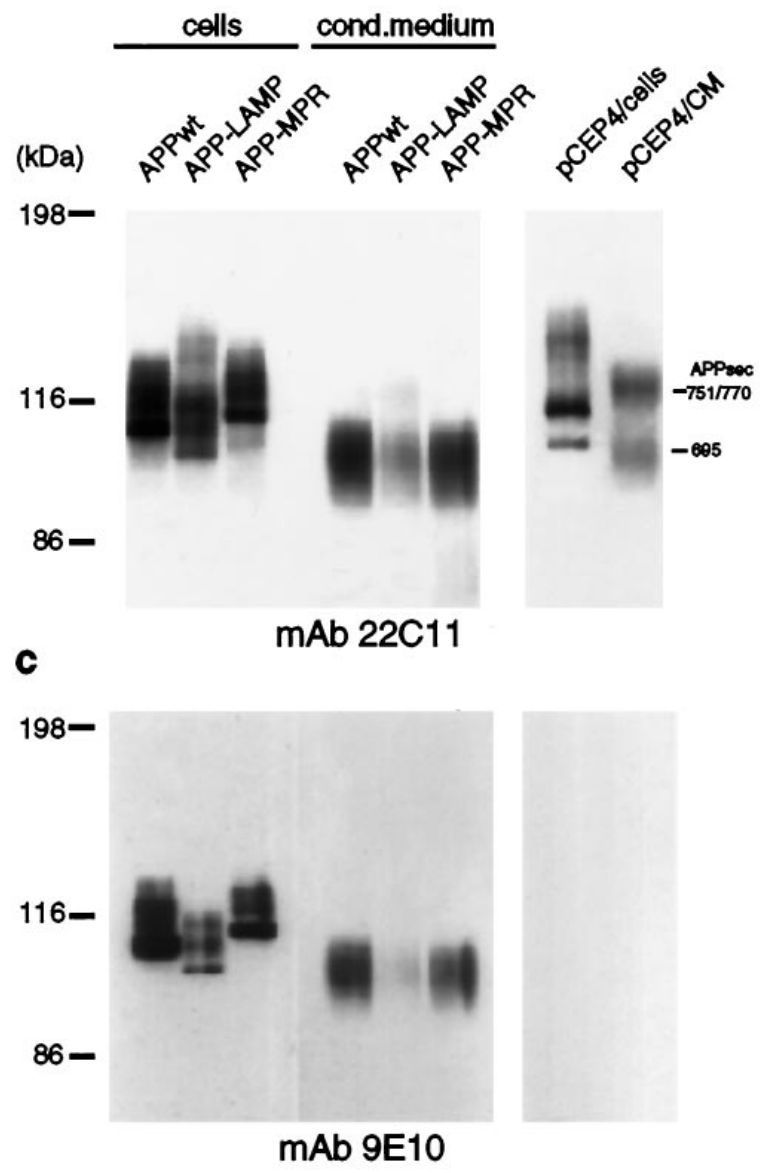

Figure 1. Expression of APP-LAMP and APP-MPR by stably transfected SY5Y cells. $a$, Schematic representation of APP695 (APPwt) and the APP chimera $A P P-L A M P$ and $A P P-M P R$, which contain the cytoplasmic domain of hLAMP-1 and CD-MPR, respectively. The proteins are $\mathrm{N}$-terminally tagged to a 10 aa c-myc sequence. $b$, Detection of the chimeric APP proteins by immunoblotting. SY5Y cells stably transfected with $A P P w t, A P P-L A M P, A P P-M P R$, or the $p C E P 4$ expression vector alone were lysed and cell-associated, and secreted APP proteins were immunoprecipitated with Fd-APP antiserum. Proteins were separated on a 7\% SDS-PAGE and analyzed by immunoblotting, using $\mathrm{mAb} 22 \mathrm{C} 11 . c$, The same filter was used for a second detection of the APP proteins with $\mathrm{mAb} 9 \mathrm{E} 10$. Because this antibody does not react with endogenous APP, the bands represent the chimeric proteins. $C M$, Conditioned medium. antibodies as used before (Fig. $2 e, f$ ). In comparison to untreated cells (Fig. $2 a$ ), leupeptin clearly stabilized the APP-LAMP chimera within vesicular structures, most of which were found to colocalize with anti-hLAMP-1 immunoreactivity (Fig. $2 e, f$; see arrows). In contrast, in the presence of leupeptin, colocalization of APPwt with endogenous hLAMP-1 within vesicular structures was less pronounced (Fig. $2 g, h$ ).

Next we examined the intracellular localization of the APPMPR chimeric protein. APP-MPR transfected SY5Y cells were incubated with mAb 9E10 (Fig. $2 i$ ) and with an antiserum recognizing the N-terminal domain of the human cationindependent mannose 6-phosphate receptor (CI-MPR; Fig. $2 j$ ), which has been shown to be localized in the same compartments as the CD-MPR (Klumperman et al., 1993). The staining pattern of APP-MPR was very similar to that of the endogenous CI-MPR (Fig. $2 i, j$ ). In contrast, APPwt was also present outside this perinuclear region, which is passed by the precursor protein following the secretory pathway (Fig. $2 k, l$ ).

\section{In accordance with their maturation and secretion, APP-MPR, but not APP-LAMP, is detectable on the cell surface}

To examine the presence of the APP proteins at the cell surface, we biotinylated on ice and lysed the intact SH-SY5Y cells stably transfected with APPwt, APP-LAMP, and APP-MPR; the labeled cell surface proteins were immunoprecipitated with antibodies directed against biotin. Remaining cell surface and intracellular APP proteins were immunoprecipitated from the same cell lysates with Fd-APP antiserum and detected by immunoblotting with $\mathrm{mAb} 22 \mathrm{C} 11$. As shown in Figure $3 a$, biotinylated APPwt and APP-MPR were observed, indicating that these proteins are present on the cell surface. The $97 \mathrm{kDa}$ band revealed by APPwt transfected cells seems to correspond to secreted APPwt associated with the cell surface, because it was not recognized by antibodies to the $\mathrm{C}$ terminus of APP but could be detected by mAb 9E10 (data not shown). Biotinylated APP-LAMP could not be detected under these conditions, indicating its predominant intracellular transport (Fig. $3 a$ ).

Because the altered intracellular transport might have an influence on the processing and secretion of the APP chimeras, pulse chase experiments were performed. Therefore, stably transfected cells were labeled metabolically with $\left[{ }^{35} \mathrm{~S}\right]$ methionine for 8 min and either lysed immediately or chased in complete, methionine-enriched medium for the times indicated (Fig. 3b).

Maturation of all APP cell-associated proteins reached a maximum intensity at $30 \mathrm{~min}$ chase time. Concurrent with the decrease of cellular mature forms, an increase of secreted species (APPs) in the conditioned medium after 60-120 min was observed. Secretion of the APP-LAMP transfected cells was clearly decreased, as compared with APPwt cells. The reduced processing by $\alpha$-secretase might be an indication of a mainly intracellular transport of APP-LAMP, because $\alpha$-secretase has been suggested to cleave in a late compartment of the secretory pathway (Sambamurti et al., 1992; Sisodia, 1992).

\section{Amyloidogenic processing of the chimeric proteins APP-LAMP and APP-MPR}

We first examined the formation of the C-terminal fragments corresponding to $\mathrm{A} 4 \mathrm{CT}$ and $\mathrm{p} 3 \mathrm{CT}$ arising from the activity of $\beta$-secretase and $\alpha$-secretase on the chimeric proteins, respectively (Fig. 4a). Cell lysates of metabolically labeled SY5Y cells expressing APPwt, APP-LAMP, and APP-MPR were prepared and normalized to the expression levels of transfected APP, which 

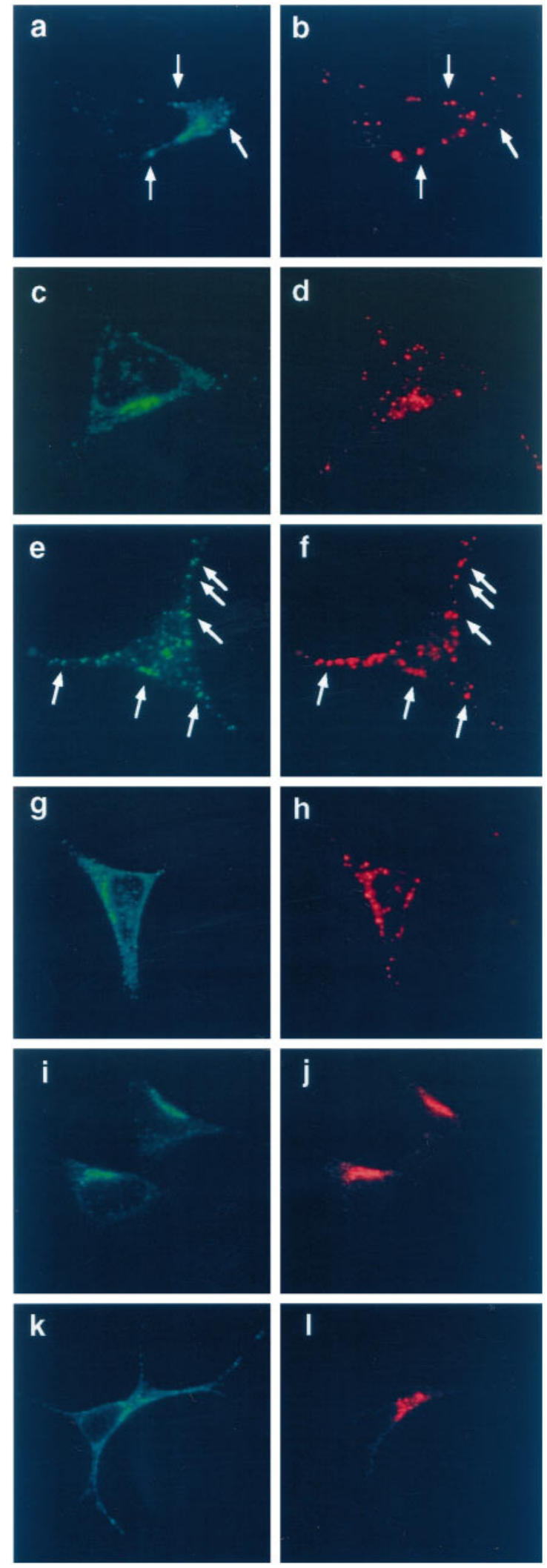

\section{APP-LAMP}

APPwt

\section{APP-LAMP +leupeptin}

\section{APPwt +leupeptin}

APP-MPR

APPwt
Figure 2. Colocalization of APP-LAMP and APP-MPR with endogenous hLAMP-1 and CI-MPR by immunofluorescence confocal microscopy. SY5Y cells stably transfected with APP-LAMP $(a, b, e, f)$, APP-MPR $(i, j)$, and APPwt $(c, d, g$, $h, k, l)$ were incubated with polyclonal A-14 $(a, c, e, g)$ or monoclonal mAb 9E10 $(i, k)$ anti-c-myc antibodies and with DTAF-conjugated second antibodies for the detection of the chimeric proteins. Monoclonal antibodies to human LAMP-1 $(b, d, f, h)$ or antiserum to CI-MPR $(j, l)$ and LRSCconjugated second antibodies were used for the detection of the corresponding endogenous marker proteins. Where indicated, cells were incubated in the presence or absence of 1 $\mathrm{mg} / \mathrm{ml}$ leupeptin $4 \mathrm{hr}$ before $\mathrm{MeOH}$ fixation. In $a, b, e$, and $f$, colocalization of APP-LAMP with endogenous hLAMP-1 within vesicular structures is marked by arrows. Leupeptin treatment in $e$ and $f$ resulted in a strong stabilization of APP-LAMP in vesicular structures, most of which colocalized with endogenous hLAMP-1. APPwt mainly colocalized with APP-LAMP in a perinuclear region, which probably is passed by both proteins during their biosynthetic pathways. $i$ and $j$ show colocalization of APP-MPR with CI-MPR, whereas the immunoreactivity of APPwt in $k$ only partially overlaps with that of CI-MPR. were determined previously in a separate experiment (see Fig. $4 c$ ). The $\mathrm{C}$-terminal fragments were immunoprecipitated with mAb 4G8 (anti- $\beta A 4$ 17-24), which recognizes both cleavage products, and $\mathrm{mAb}$ WO2 (anti- $\beta \mathrm{A} 4$ 1-16), which detects the A4CT fragments, but not p3CT (Fig. 4a).
A4CT and p3CT fragments were detectable in the cell lysates of all three cell lines (Fig. 4b). In comparison to APPwt, the corresponding A4CT and p3CT cleavage products of $\sim 14.2$ and $12.2 \mathrm{kDa}$ were highly enriched in the APP-MPR transfected cells. This might indicate that the APP-MPR chimeric proteins like 
a

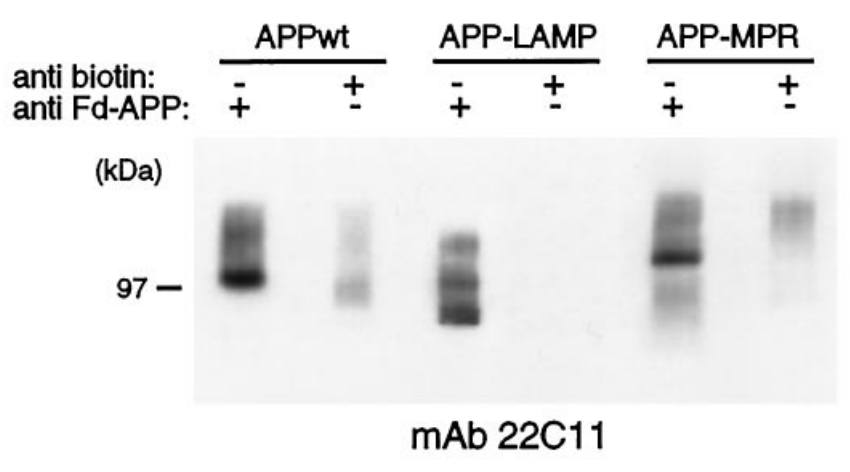

b

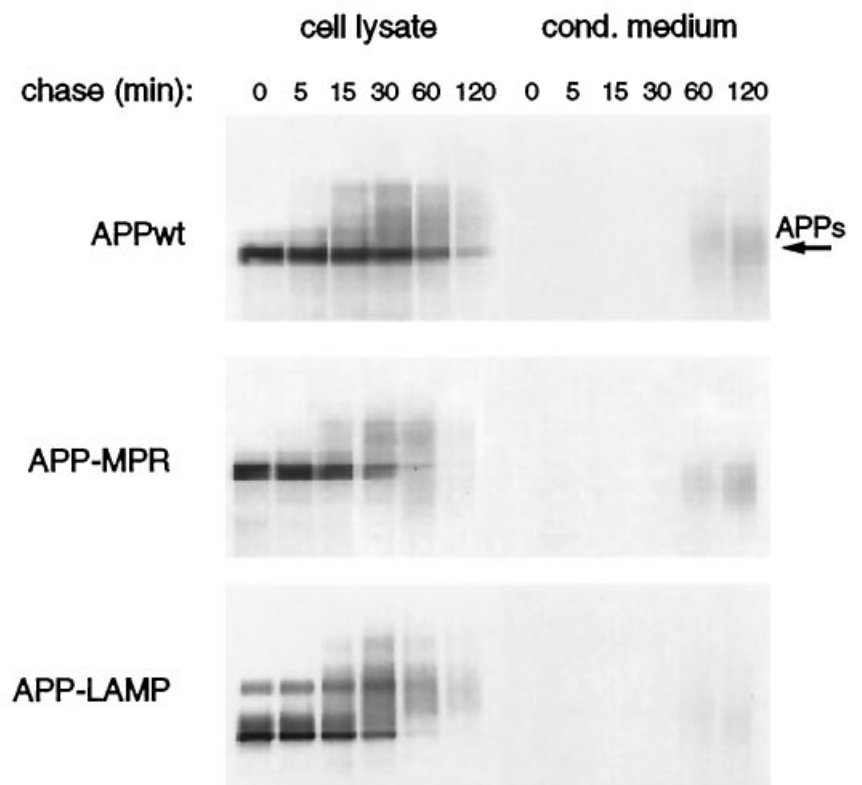

Figure 3. Cell surface expression and maturation of APP-LAMP and APP-MPR. $a$, The intact cells, expressing APPwt, APP-LAMP, and APP-MPR, were labeled with sulfo-NHS-biotin, as described in Materials and Methods. Biotinylated cell surface proteins were immunoprecipitated with anti-biotin antibodies, followed by an incubation with Fd-APP antiserum and analyzed by immunoblotting with $\mathrm{mAb} 22 \mathrm{C} 11$. In contrast to APPwt and APP-MPR, biotinylated APP-LAMP was not detectable. $b$, Pulse chase analysis of the stably transfected cells. After being labeled with $\left[{ }^{35} \mathrm{~S}\right]$ methionine for $8 \mathrm{~min}$, the cells were chased in methionineenriched growth medium for the times as indicated. Cell-associated and secreted APP proteins were immunoprecipitated with Fd-APP antiserum and analyzed by SDS-PAGE and autoradiography. In comparison to APPwt and APP-MPR, a reduced secretion of APP-LAMP was observed. APPs, Secreted APP (arrow).

CD-MPR do not enter the proteolytically active lysosomes, because it has been suggested that $\mathrm{C}$-terminal fragments become degraded in lysosomes (Busciglio et al., 1993; Haass and Selkoe, 1993; Siman et al., 1993). In contrast, the $8.4 \mathrm{kDa}$ A4CT of the APP-LAMP chimeric protein was decreased in cells stably transfected with APP-LAMP. The corresponding p3CT cleavage product $(6.4 \mathrm{kDa})$ was hardly detectable, confirming the reduced processing by $\alpha$-secretase shown in the pulse chase experiment.
Next, we looked for the generation of $\beta \mathrm{A} 4$ arising from the action of $\beta$ - and $\gamma$-secretase and the $3 \mathrm{kDa}$ peptide $\mathrm{p} 3$, produced by $\alpha$ - and $\gamma$-cleavage.

Importantly, in contrast to APPwt transfected cells, neither $\beta \mathrm{A} 4$ nor $\mathrm{p} 3$ was detectable in the conditioned medium of cells stably transfected with APP-LAMP by immunoprecipitation with $\beta A 4_{1-40}$ antiserum (Fig. $4 d$ ). However, both cleavage products were found in the medium of APP-MPR transfected cells. The amount of these fragments was decreased to $\sim 50 \%$, as compared with APPwt cells, but the ratio of $\beta \mathrm{A} 4$ to $\mathrm{p} 3$ appeared unaltered in comparison to APPwt, as confirmed by phosphorimaging.

To examine the species of $\beta \mathrm{A} 4$ that are secreted from APPwt and APP-MPR-expressing cells, we performed immunoprecipitation of the conditioned media with monoclonal antibodies specifically recognizing the $\beta \mathrm{A} 4_{1-40}$ form and the longer $\beta \mathrm{A} 4_{1-42}$, respectively. Secreted $\beta A 4$ was immunoprecipitated with $\mathrm{mAb}$ G2-10, which reacts specifically with $\beta A 4_{1-40}$ (Ida et al., 1996) (Fig. $4 e$ ). In contrast, the longer $\beta \mathrm{A} 4_{1-42}$ could not be detected in the medium of the transfected cells by immunoprecipitation with the $\beta \mathrm{A} 4_{1-42}$-specific antibody G2-11 (Ida et al., 1996).

\section{Synthesis and secretion of the chimeric proteins APP- SDYQRL and APP-KKLN}

Because we showed that the APP-MPR chimeric protein becomes processed into secreted $\beta A 4$ to a lesser extent than APPwt, other sites aside from late endosomes may be involved in the generation of secreted $\beta \mathrm{A} 4$. To examine whether the late secretory pathway leads to the formation of $\beta A 4$, we constructed an APP695 protein C-terminally tagged with the cytoplasmic signal sequence SDYQRL of TGN38, a marker protein of the TGN. Because this sequence is responsible for the retrieval of TGN38 from the cell surface to the TGN (Ponnambalam et al., 1994), we expected a similar targeting for the APP chimeric protein, which we termed APP-SDYQRL (Fig. 5a). Another chimeric protein was constructed, bearing a di-lysine-based ER retention signal at the C terminus of APP695 (Fig. 5a), to investigate the role of the ER in the generation of secreted $\beta A 4$.

Both APP fusion constructs were N-terminally c-myc-tagged and cloned into the expression vector pCEP4; stable SH-SY5Y cell lines were established. The expression of the chimeric proteins was examined by immunoprecipitation of the cell lysates and conditioned media with Fd-APP and c-myc antisera (Fig. 5b). Approximately equal amounts of the expressed proteins were obtained in the three cell lines. The higher molecular weight of secreted APP-SDYQRL might indicate elevated processing in the TGN as compared with APPwt or an alternative cleavage by $\alpha$-secretase. In contrast, secreted protein was hardly detectable in APP-KKLN transfected cells, suggesting a predominant intracellular presence of this protein.

\section{Colocalization of APP-SDYQRL and APP-KKLN with TGN and ER markers is consistent with their predicted distributions}

We used double-labeling confocal immunofluorescence experiments to study the intracellular localization of APP-SDYQRL and APP-KKLN. In APP-SDYQRL-expressing cells most of APP-SDYQRL, stained with mAb 9E10, and TGN38, detected by a TGN38 antiserum, colocalized to the same perinuclear location (Fig. 6a,b). Immunofluorescent visualization of APPwt transfected cells resulted in costaining of APPwt and TGN38 in the perinuclear region, because the precursor protein passes the Golgi complex on its way to the cell surface (Fig. $6 c, d$ ). In SY5Y cells transfected with APP-KKLN, colo- 
a

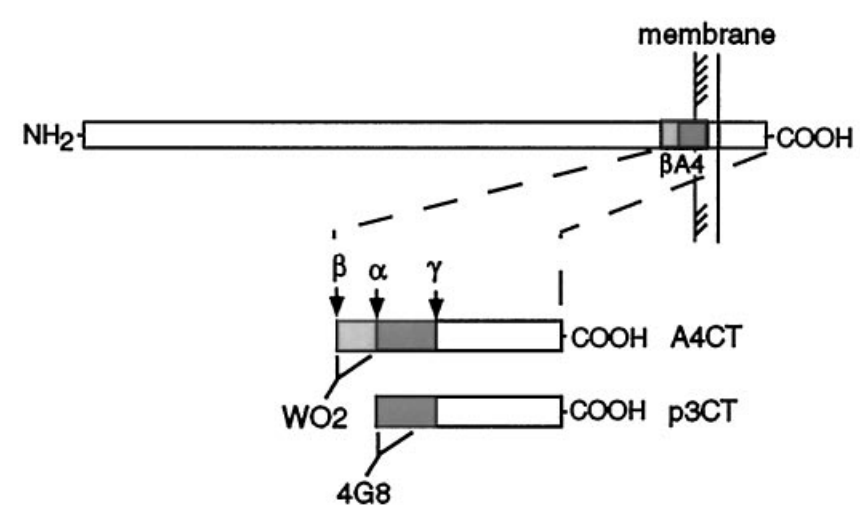

b

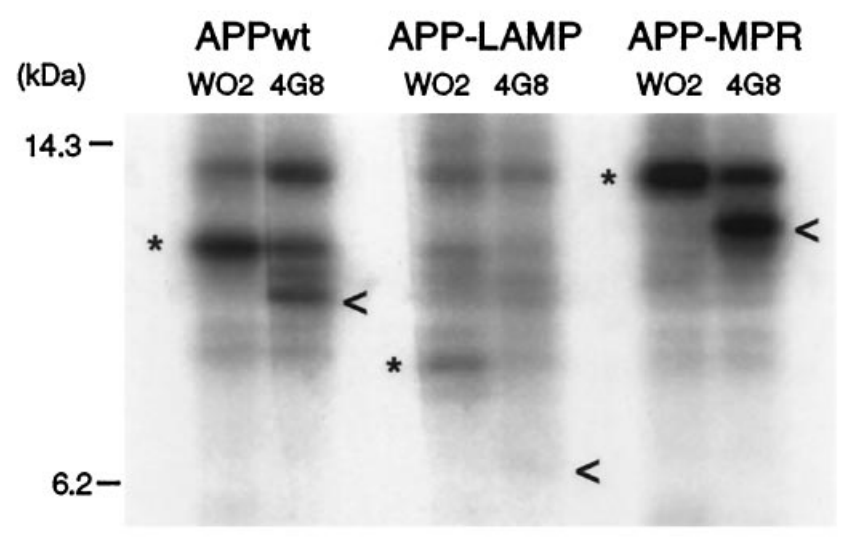

\section{C}

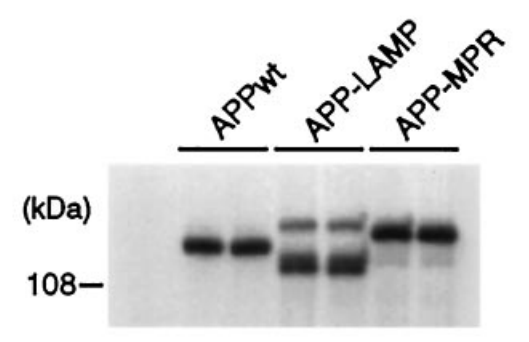

d

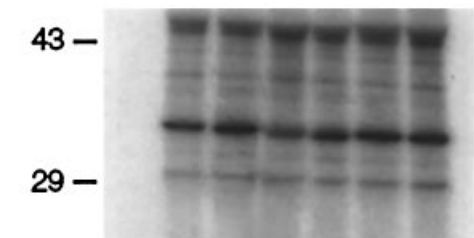

$\mathbf{e}$
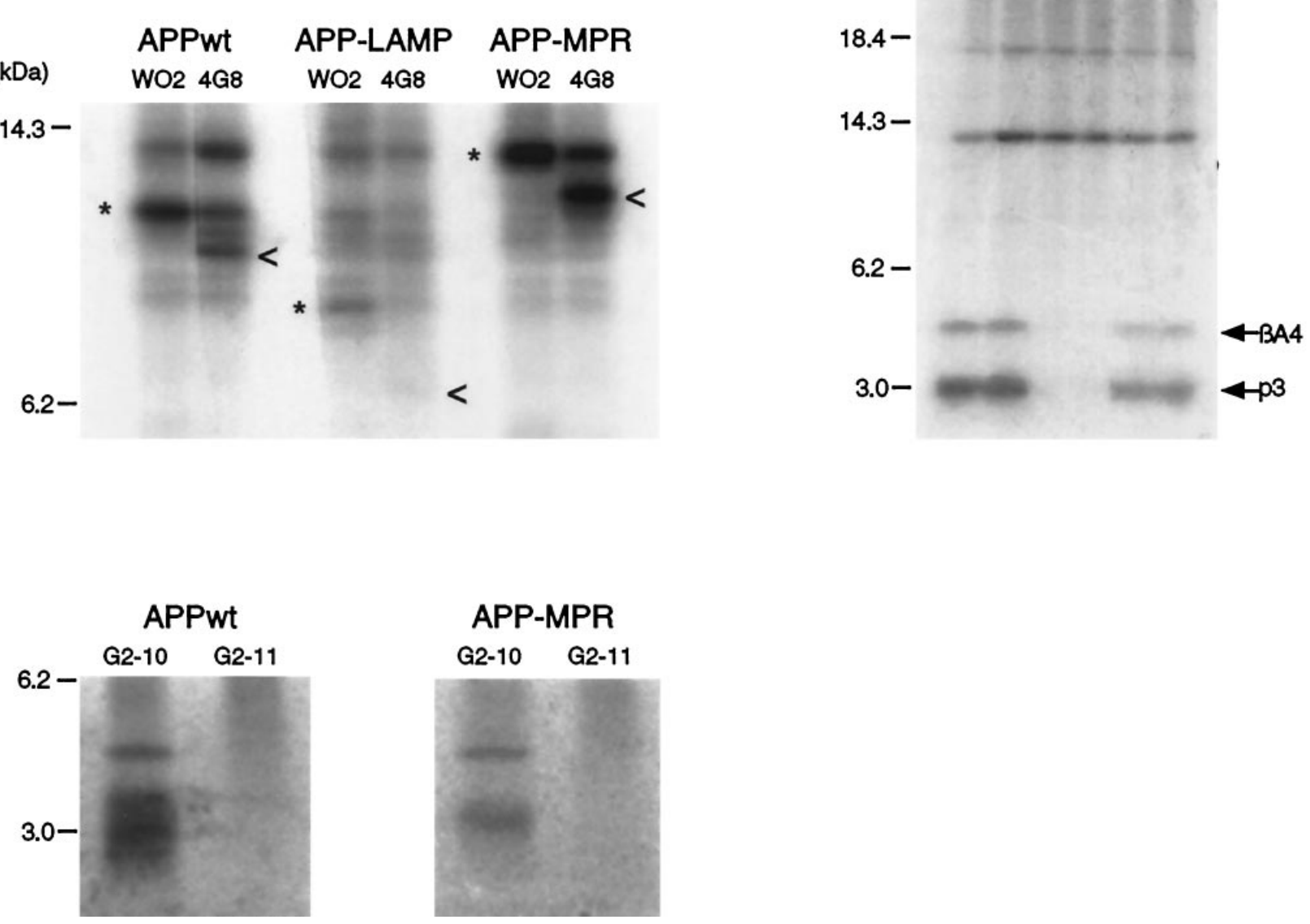

Figure 4. Processing of APPwt, APP-LAMP, and APP-MPR into amyloidogenic fragments. $a$, Schematic representation of APP, A4CT, and p3CT, generated by $\alpha$ - and $\beta$-cleavage and the recognition sites of mAb $4 G 8$ (anti- $\beta \mathrm{A} 4$ 17-24) and mAb WO2 (anti- $\beta \mathrm{A} 4$ 1-16). $b, \mathrm{C}$-terminal cleavage products of the chimeric proteins arising by the activity of $\alpha$ - and $\beta$-secretase. SY5Y cells stably expressing APPwt, APP-LAMP, and APP-MPR were labeled metabolically with $\left[{ }^{35} \mathrm{~S}\right]$ methionine for $4 \mathrm{hr}$. Immunoprecipitation of the cell lysates was performed with mAb $4 G 8$ and mAb WO2. Precipitates were analyzed by SDS-PAGE and autoradiography. Bands marked by an asterisk (*) correspond to A4CT fragments of APPwt (12 kDa), APP-LAMP (8.4 $\mathrm{kDa})$, and APP-MPR $(14.2 \mathrm{kDa})$ and those labeled by an arrowhead $(<)$ correspond to APPwt $(10 \mathrm{kDa})$, APP-LAMP $(6.4 \mathrm{kDa})$, and APP-MPR $(12.2$ $\mathrm{kDa}$ ) $3 \mathrm{CT}$ cleavage products. In comparison to APPwt, A4CT and p3CT equivalents of APP-MPR transfected cells were highly enriched, whereas in APP-LAMP-expressing cells the amount of A4CT was reduced and that of p3CT fragments was strongly decreased. $c$, Stably transfected cells were labeled metabolically with $\left[{ }^{35} \mathrm{~S}\right]$ methionine for $10 \mathrm{~min}$ and lysed immediately. According to their expression levels, corresponding amounts of cells were used for immunoprecipitation with Fd-APP antiserum. Precipitates were analyzed by SDS-PAGE and autoradiography. The autoradiogram shows that comparable amounts of APPwt, APP-LAMP, and APP-MPR chimeric proteins were used. $d$, Detection of secreted $\beta A 4$ and $p 3$ (arrows). Stably transfected cells were labeled metabolically with ${ }^{35}$ S $]$ methionine for $16 \mathrm{hr}$, and the conditioned medium corresponding to their expression level was incubated with $\beta \mathrm{A} 4_{1-40}$ antiserum. Immunoprecipitates were analyzed by SDS-PAGE and autoradiography. In APP-MPR transfected cells the secretion of $\beta A 4$ and $p 3$ was decreased to $\sim 50 \%$, as compared with APPwt. In the medium of APP-LAMP-expressing cells neither $\beta A 4$ nor $p 3$ was detectable. $e$, To distinguish between $\beta \mathrm{A} 4_{1-40}$ and $\beta \mathrm{A} 4_{1-42}$, we radioactive-labeled the APPwt and APP-MPR transfected cells, as described in $d$, and equal volumes of conditioned media were used for immunoprecipitation with $G 2-10$, specifically recognizing $\beta \mathrm{A} 4_{1-40}$, or $G 2-11$, specific for $\beta \mathrm{A} 44_{1-42}$. $\beta \mathrm{A} 4$ and $\mathrm{p} 3$ were precipitated by $G 2-10$, but not by $G 2-11$. 
a
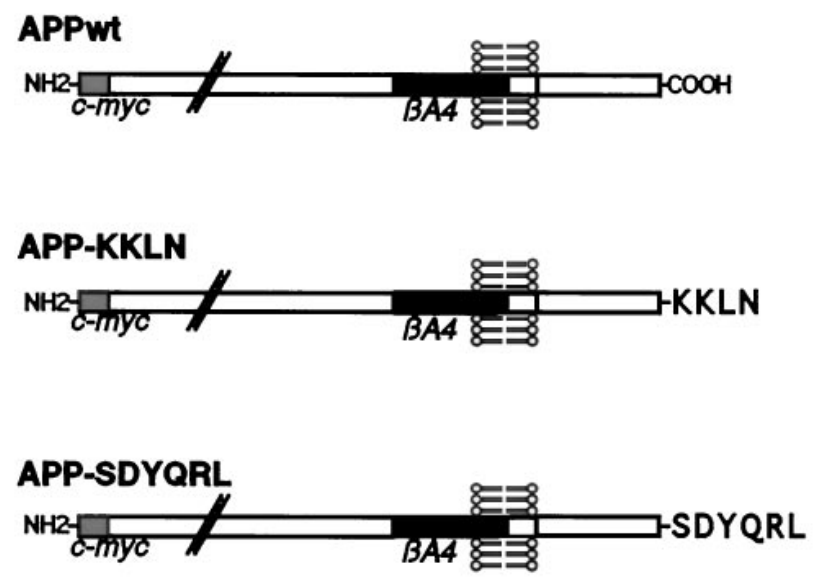

b

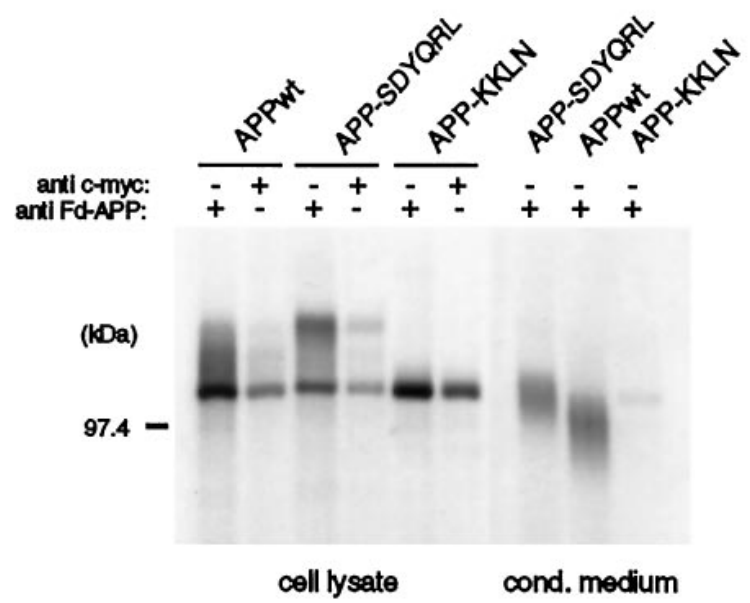

Figure 5. Expression of APP-SDYQRL and APP-KKLN chimeras by SY5Y cells. $a$, Schematic representation of $A P P-S D Y Q R L$ and $A P P-K K L N$. Both proteins were N-terminally c-myc-tagged. $b$, For detection of $A P P$ $S D Y Q R L$ and $A P P-K K L N$, stably transfected SY5Y cells were labeled with $\left[{ }^{35} \mathrm{~S}\right]$ methionine, and immunoprecipitation of equal amounts of the cell lysates was performed with Fd-APP and c-myc antisera. Conditioned medium of the transfected cells was incubated with Fd-APP antiserum. Immunoprecipitates were analyzed by SDS-PAGE and autoradiography. Similar amounts of cell-associated $A P P w t, A P P-S D Y Q R L$, and $A P P-K K L N$ proteins were detected. In contrast to $A P P w t$ and $A P P-S D Y Q R L$, secreted protein was hardly detectable in $A P P-K K L N$-expressing cells.

calization of APP-KKLN and the ER resident sec61, which was detected by a sec61 antiserum, was observed (Fig. $6 e, f$ ). APPwt cells also showed colocalization of APPwt with sec61 (Fig. $6 g, h$ ) but this again probably was attributable to the passage of APP through the secretory pathway, because additional staining like that of the perinuclear region was observed for the APPwt protein.

Cell surface expression and maturation of APPSDYQRL and APP-KKLN correspond to the altered intracellular trafficking

To examine whether APP-SDYQRL and APP-KKLN are transported to the plasma membrane, we labeled cell surface proteins of the stably transfected SY5Y cells with biotin and analyzed them as described in Figure $3 a$. The mature form of APPSDYQRL (top band) was found to become biotinylated, which is in agreement with its recycling between TGN and the plasma membrane (Fig. 7a). In contrast, biotinylated APP-KKLN was not observed, indicating the mainly intracellular localization of this protein. This is also in accordance with the lack of carbohydrate maturation and secretion of APP-KKLN examined in a pulse chase experiment (Fig. 7b). In contrast, APP-SDYQRL becomes matured and is secreted.

\section{Amyloidogenic processing of APP-SDYQRL and APP-KKLN}

To study the amyloidogenic processing of APP-SDYQRL and APP-KKLN, we examined the activity of $\beta$-secretase by the formation of the C-terminal fragments corresponding to A4CT. $\alpha$-Secretase activity was studied by detection of p3CT equivalents (see Fig. 4a).

SH-SY5Y cells stably transfected with APPwt, APP-SDYQRL, and APP-KKLN were labeled metabolically with $\left[{ }^{35} \mathrm{~S}\right] \mathrm{methi}-$ onine and $\mathrm{A} 4 \mathrm{CT}$, and $\mathrm{p} 3 \mathrm{CT}$ cleavage equivalents were immunoprecipitated by mAb WO2 and 4G8 (Fig. 8a). Both C-terminal fragments were observed in the cell lysates of APP-SDYQRL and APPwt transfected cells. Two protein bands in the molecular weight range of APP-SDYQRL-p3CT were detected by $\mathrm{mAb}$ 4G8 in the cell lysate of APP-SDYQRL-expressing cells, which might correspond to alternative $\alpha$-cleavage products. Neither p3CT nor A4CT equivalents were detectable in the cell lysate of APP-KKLN transfected cells.

To examine the processing of APP-SDYQRL and APP-KKLN into secreted $\beta \mathrm{A} 4$ and $\mathrm{p} 3$, we incubated equal amounts of conditioned medium of APPwt and APP-SDYQRL and an excess of APP-KKLN-conditioned medium with $\beta A 4_{1-40}$ antiserum recognizing $\beta \mathrm{A} 4$ and $\mathrm{p} 3$ in an immunoprecipitation experiment. Even higher amounts of $\beta \mathrm{A} 4$ could be detected in the conditioned medium of APP-SDYQRL transfected SY5Y cells, as compared with APPwt cells (Fig. 8b). When we analyzed the species of secreted $\beta \mathrm{A} 4$, we found that $\beta \mathrm{A} 4$ and $\mathrm{p} 3$ were immunoprecipitated by the mAb G2-10, specific for $\beta A 4_{1-40}$, but not by $\mathrm{mAb}$ G2-11, which reacts specifically with $\beta \mathrm{A} 4_{1-42}$ (Fig. $8 c$ ). Neither $\beta \mathrm{A} 4$ nor $\mathrm{p} 3$ could be detected in the conditioned medium of APP-KKLN transfected cells.

\section{DISCUSSION}

\section{Subcellular distribution of the APP chimeras}

APP that follows the secretory pathway from the ER to the plasma membrane is partially secreted. In addition, cell surface APP can be internalized into the cell and recycle rapidly to the plasma membrane, can undergo amyloidogenic processing to $\beta \mathrm{A} 4$ peptide, or can be transported to lysosomes for complete degradation (Caporaso et al., 1992; Haass et al., 1992a; Koo et al., 1996; Yamazaki et al., 1996).

To investigate the role of several compartments like the endosomal/lysosomal system, the secretory pathway, and the ER in the processing of APP into the secreted $\beta$ A4 peptide, we analyzed the transport and processing of APP chimeras bearing $\mathrm{C}$-terminal sorting sequences believed to serve as targeting signals for the corresponding sites of the cell.

Three independent approaches were performed to demonstrate that the intracellular sorting of the APP hybrids was altered in accordance with their new cytoplasmic sorting signals. First, we demonstrated by immunofluorescence confocal microscopy that, 

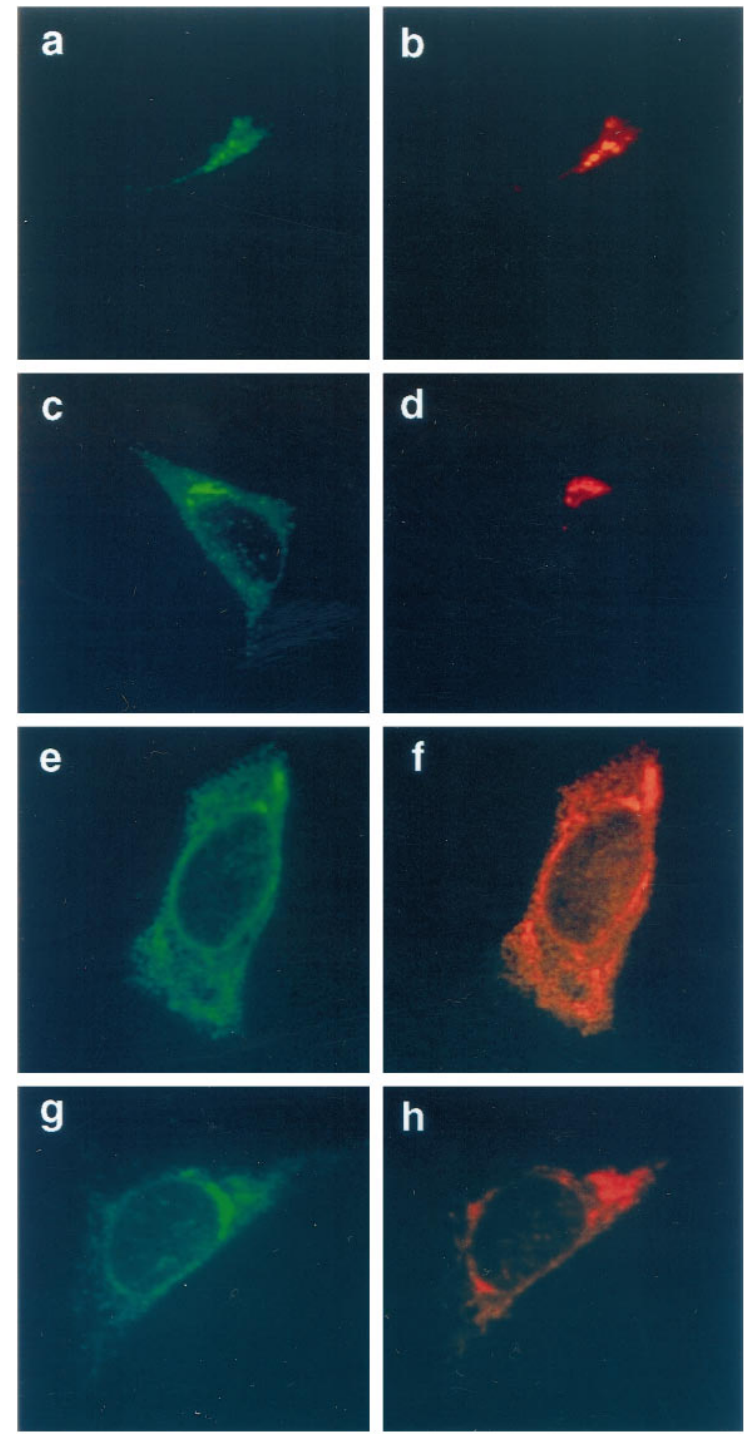

\section{APPwt}

only in the presence of leupeptin, strong vesicular immunoreactivity of APP-LAMP was detectable, which overlapped with that of the lysosomal marker protein hLAMP-1. APP-MPR was visualized clearly in the same regions that reacted with antibodies against CI-MPR known to enter the same compartments as CD-MPR (Klumperman et al., 1993), like the Golgi apparatus and late endosomes. Colocalization of APP-SDYQRL with TGN38 clearly showed that both proteins were concentrated to the same perinuclear area and that the ER resident sec61 revealed an almost identical staining pattern as APP-KKLN.

Second, cell surface biotinylation demonstrated that APPMPR and APP-SDYQRL are transported to the plasma membrane. This is in agreement with the trafficking of endogenous CD-MPR and TGN38, which have been described to recycle to the cell surface (Kornfeld, 1992; Reaves et al., 1993). Neither APP-LAMP nor APP-KKLN was found to be accessible for biotinylation at the cell surface, confirming an altered trafficking of these chimeras to a mainly intracellular routing.

Finally, metabolic labeling revealed that the maturation of APP-LAMP, APP-MPR, and APP-SDYQRL are concordant with the trafficking of the corresponding cognate proteins. The secretion of APP-LAMP, as compared with APPwt, was strongly reduced. Because the amount of cell-associated APP-LAMP did

\begin{abstract}
Figure 6. Colocalization of APP-SDYQRL and APPKKLN with TGN38 and the ER resident sec61, respectively, was analyzed by immunofluorescence confocal microscopy. SY5Y cells stably expressing APPwt $(c, d, g, h)$, APPSDYQRL $(a, b)$, and APP-KKLN $(e, f)$ were incubated with mAb 9E10 $(a, c, e, g)$ for the detection of the c-myc-tagged APP proteins, visualized by using DTAF-coupled second antibodies and $\operatorname{TGN} 38(b, d)$ or sec61 antiserum $(f, h)$, followed by a second antibody conjugated with LRSC. Most of APP-SDYQRL colocalized with endogenous TGN38 in a perinuclear region $(a, b)$. In contrast, APPwt also was found outside this juxtanuclear area $(c)$. $e$ and $f$ show that APPKKLN colocalized with endogenous sec61, whereas additional staining was observed for the APPwt protein $(g)$.
\end{abstract}

not increase proportionally with the decrease of secreted protein, it seems likely that this chimeric protein becomes rapidly degraded. This might indicate transport to lysosomes. APP-KKLN, which does not undergo secretion, also failed to be matured during the labeling period, consistent with its retention in the ER.

Therefore, although it cannot be excluded that a small fraction of the APP hybrids becomes missorted, we believe that most of APP-LAMP, APP-MPR, APP-SDYQRL, and APP-KKLN follow the intracellular pathways mediated by the new cytoplasmic sorting signals.

\section{Amyloidogenic processing of the APP chimeras}

In SH-SY5Y cells, lysosomes seem not to be required for the formation of secreted $\beta$ A4, because APP-LAMP that was targeted directly into lysosomes was not processed into secreted $\beta A 4$. This is in agreement with previous findings demonstrating that release of $\beta A 4$ is not inhibited by leupeptin and that $\beta \mathrm{A} 4$ is not detectable in isolated lysosomes (Shoji et al., 1992; Haass et al., 1993). The lack of $\beta A 4$ secretion from cells transfected with APP-LAMP is probably not attributable to absence of $\beta$ secretase cleavage. We found APP-LAMP to be cleaved by a protease with similar activity like $\beta$-secretase into a corresponding A4CT fragment. It is unlikely that the cleavage occurred in 
a

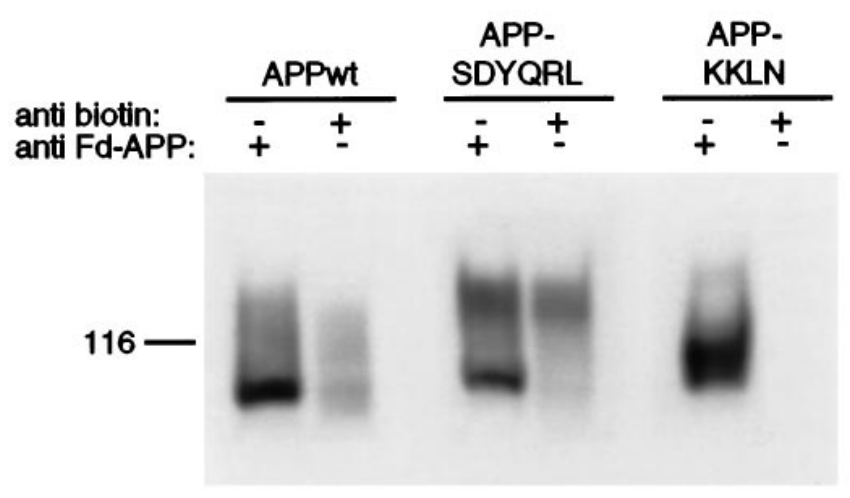

b

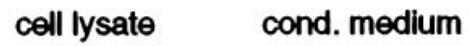

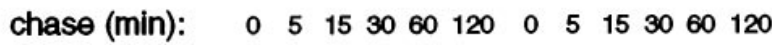

APP-SDYQRL

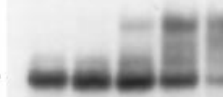

APPs

\section{APP-KKLN}

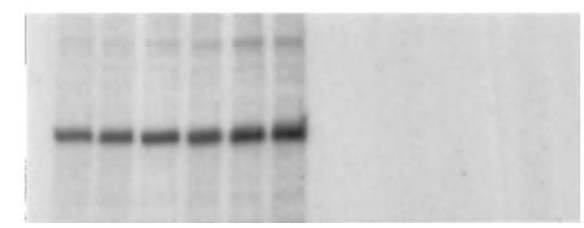

Figure 7. Analysis of the maturation and cell surface expression of APP-SDYQRL and APP-KKLN in transfected SY5Y cells. $a$, Plasma membrane proteins were labeled with sulfo-NHS-biotin on ice, and the biotinylated proteins were immunoprecipitated with biotin antiserum. A second immunoprecipitation with the same cell lysates was performed by using Fd-APP antiserum. The precipitated APP proteins were analyzed by SDS-PAGE and by immunoblotting with mAb 22C11. APPwt and APP-SDYQRL were found to become biotinylated; biotinylated APPKKLN was not observed. $b$, Pulse chase analysis of APPwt-, APPKKLN-, and APP-SDYQRL-expressing cells was performed as described in Figure $3 b$. The APP-KKLN and APP-SDYQRL proteins were immunoprecipitated with c-myc and Fd-APP antiserum, respectively. In contrast to APP-SDYQRL, in cells expressing APP-KKLN no carbohydrate processing and no secretion of APP-KKLN were observed.

lysosomes, because APP-MPR appeared also to be processed into a similar C-terminal fragment, assumed to be generated by the same $\beta$-secretase activity. A4CT derived from APP-MPR was highly stabilized, which was also the case for $\mathrm{p} 3 \mathrm{CT}$. This indicates that APP-MPR probably does not enter the lysosomes that are involved in the degradation of the C-terminal fragments (Busciglio et al., 1993; Haass et al., 1993; Siman et al., 1993). Because APP-SDYQRL also appeared to be cleaved by a $\beta$-secretase, it seems likely that one or several compartments passed by all three APP proteins contain this cleavage activity, provided that it is the same in all three cases. The ER seemed not to be involved in this proteolytic processing, because $\beta$-cleavage products of APP-
KKLN and also secreted $\beta A 4$ were not observed. This is consistent with previous findings, which demonstrated that brefeldin A treatment resulted in a complete inhibition of $\beta \mathrm{A} 4$ secretion (Busciglio et al., 1993; Haass et al., 1993).

Besides the ER, early and late endosomes and the Golgi complex seem to be passed by APP-LAMP, APP-MPR, and APPSDYQRL and therefore represent possible compartments containing a $\beta$-secretase activity. APP-LAMP that follows the intracellular trafficking of hLAMP-1 is transported from the TGN to the lysosomes via late endosomes and possibly also early endosomes. APP-MPR may recycle among the TGN, late endosomal structures, and the cell surface like the CD-MPR. APPSDYQRL may follow the secretory route to the plasma membrane and recycle back to the TGN via early and probably at least partially via late endosomes, because they have been shown to be passed by hybrid proteins bearing the cytoplasmic domain of TGN38 (Ponnambalam et al., 1994).

Together with previous findings, the presence of a $\beta$-secretase activity in late endosomes seems very likely to us. First, an acidic milieu has been suggested to be required for $\beta$-cleavage because chloroquine and ammonium chloride inhibit $\beta \mathrm{A} 4$ generation from full-length APP, but not from A4CT, indicating different intracellular localizations of $\beta$ - and $\gamma$-cleavage activities (Dyrks et al., 1993). Second, Koo and Squazzo (1994) demonstrated that endocytosis of intact cell surface APP via the receptor-mediated pathway leads to $\beta$ A4 release, implying that specific $\beta$-secretase activity requires internalization.

Release of $\beta A 4$ occurs with APP-MPR and APP-SDYQRL transfected cells, indicating that both proteins are processed by a $\gamma$-secretase. On condition that APP-MPR and APP-SDYQRL are cleaved by the same $\gamma$-secretase activity, this proteolytic enzyme might be localized in a compartment or compartments passed by both APP chimeras. Because APP-LAMP-expressing cells do not secrete $\beta \mathrm{A} 4$, late endosomes or lysosomes probably are not involved in $\gamma$-cleavage, leading to the release of $\beta \mathrm{A} 4$ naturally. Enrichment of A4CT and p3CT in cells stably transfected with APP-MPR in parallel with a decreased amount of secreted $\beta \mathrm{A} 4$ and $\mathrm{p} 3$ might indicate a reduced processing by $\gamma$-secretase. Because APP-SDYQRL gives rise to even higher amounts of secreted $\beta A 4$, as compared with APPwt, we hypothesize that early endosomes involved in the recycling of APP proteins to the cell surface might be required for $\beta A 4$ generation and release, whereas shuttling between TGN and late endosomal structures seems not to result in efficient $\gamma$-cleavage. Such an assumption also is supported by the finding that the generation of $\beta \mathrm{A} 4$ from A4CT is not influenced by agents that interfere with pH gradients (Dyrks et al., 1993), suggesting a less acidic milieu for the $\gamma$-secretase activity.

At least most of the $\beta$ A4 species secreted from APPwt-, APPMPR-, and APP-SDYQRL-expressing cells seem to be $\beta A 4_{1-40}$ because $\beta A 4$ of the conditioned medium was recognized by a monoclonal antibody (mAb G2-10), which specifically reacts with $\beta A 4_{1-40}$. We could not detect $\beta \mathrm{A} 4_{1-42}$ in the supernatants of the cells by immunoprecipitation with $\mathrm{mAb}$ G2-11 specific for this longer $\beta A 4$ species, which might be under the detection level of our assay.

Our results indicate a model in which lysosomes seem not to be required for the generation of secreted $\beta \mathrm{A} 4_{1-40}$. We postulate that release of the $\beta \mathrm{A} 4_{1-40} \mathrm{~N}$ terminus by a $\beta$-secretase can occur in a late endosomal compartment. Our findings strongly suggest that the ER is not involved in the APP695 processing leading to $\beta A 4_{1-40}$ secretion. In addition, our results indicate distinct com- 
a

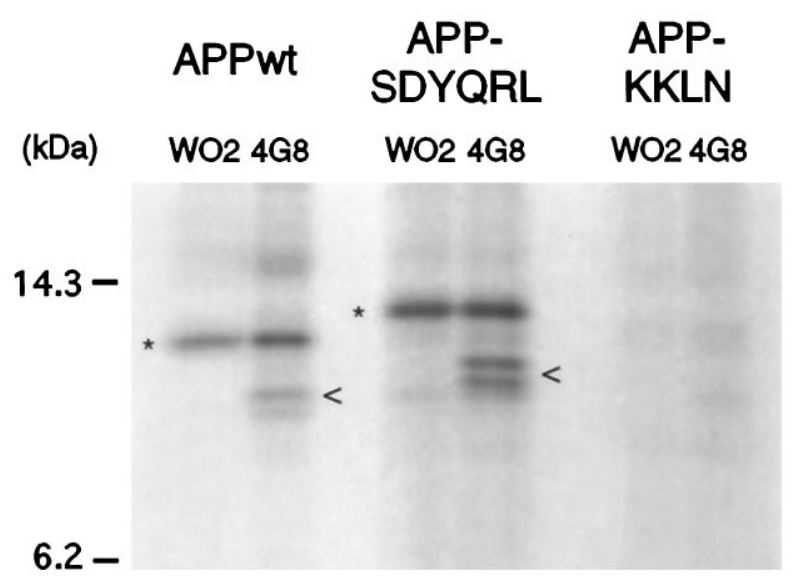

C

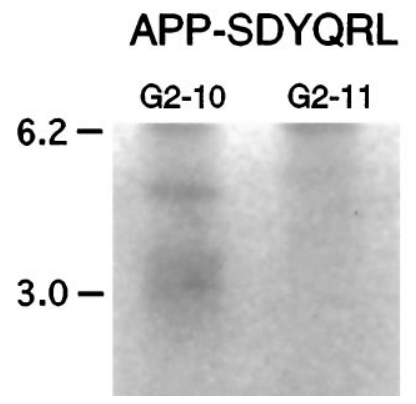

b

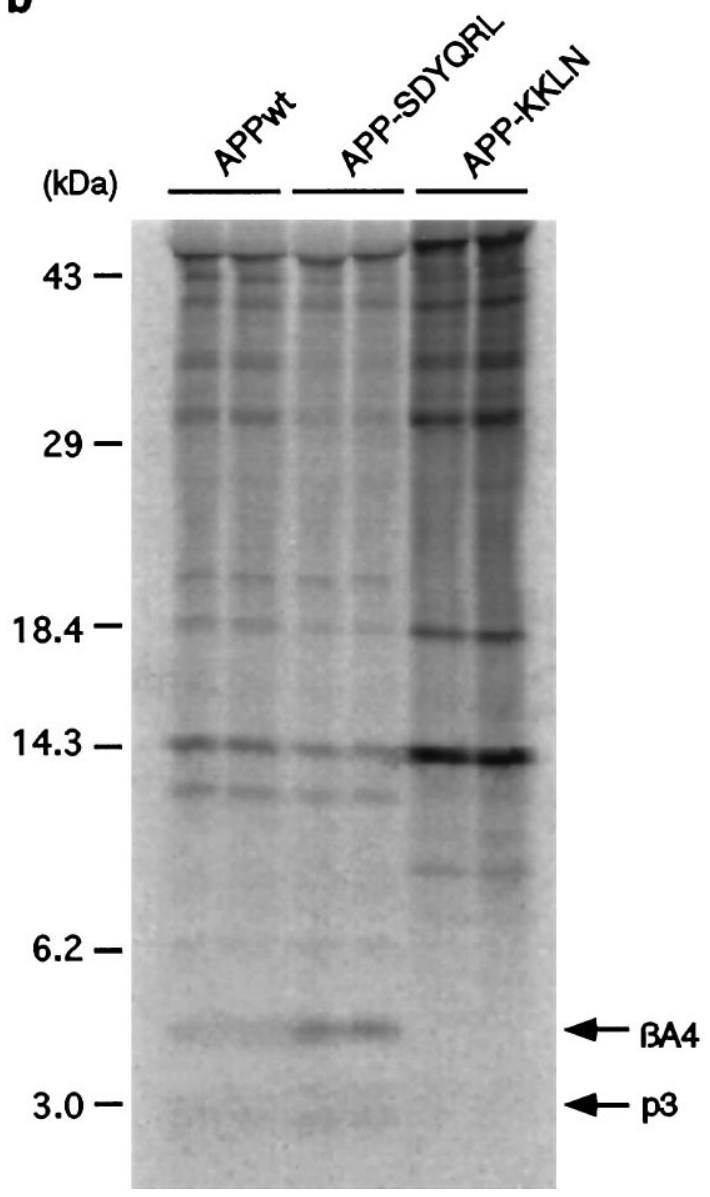

Figure 8. Amyloidogenic processing of APP-SDYQRL and APP-KKLN. SY5Y cells stably expressing APPwt, APP-SDYQRL, and APP-KKLN were labeled metabolically with $\left[{ }^{35} \mathrm{~S}\right]$ methionine. $a$, A4CT and $\mathrm{p} 3 \mathrm{CT}$ cleavage products of the cell lysates were immunoprecipitated with mAb $W 02$ and $\mathrm{mAb}$ $4 G 8$, respectively, and analyzed by SDS-PAGE and autoradiography. Bands marked by an asterisk $(*)$ correspond to A4CT equivalents of APPwt (12 $\mathrm{kDa})$ and APP-SDYQRL $(12.7 \mathrm{kDa})$. The arrowheads $(<)$ point to bands corresponding to p3CT cleavage products of APPwt $(10 \mathrm{kDa})$ and APP-SDYQRL (10.7 kDa). In APP-KKLN-expressing cells, neither A4CT nor p3CT equivalents were detectable. $b$, Immunoprecipitation of $\beta A 4$ and p3 was performed by incubation of the same volumes of conditioned medium with $\beta A 4_{1-40}$ antiserum. The samples were analyzed by SDS-PAGE and autoradiography. In comparison to APPwt, even higher amounts of $\beta \mathrm{A} 4$ were detectable in the medium of APP-SDYQRL transfected cells, whereas neither $\beta \mathrm{A} 4$ nor $\mathrm{p} 3$ was found in the medium of APP-KKLN-expressing cells. $c$, For specific detection of $\beta \mathrm{A} 4_{1-40}$ and $\beta \mathrm{A} 4_{1-42}$, the same volumes of APP-SDYQRL-conditioned medium were treated with $G 2-10$ or G2-11 in an immunoprecipitation experiment. The precipitates were analyzed by SDS-PAGE and autoradiography. Secreted $\beta A 4$ and $\mathrm{p} 3$ were precipitated by $G 2-10$, but not by $G 2-11$.

partments for $\beta$ - and $\gamma$-secretase activities, because A4CT and p3CT derived from APP-MPR are enriched in the corresponding cells in parallel with a decreased amount of secreted $\beta$ A4 and p3. The $\gamma$-cleavage activity, leading to the secretion of $\beta A 4_{1-40}$, might be localized in early endosomes. Beside APP695, which has been used for the construction of the chimeric proteins, this model awaits verification for other splice variants like APP751 or APP770.

\section{REFERENCES}

Busciglio J, Gabuzda DH, Matsudaira P, Yankner BA (1993) Generation of beta-amyloid in the secretory pathway in neuronal and nonneuronal cells. Proc Natl Acad Sci USA 90:2092-2096.

Caporaso GL, Gandy SE, Buxbaum JD, Greengard P (1992) Chloroquine inhibits intracellular degradation but not secretion of Alzheimer beta/A4 amyloid precursor protein. Proc Natl Acad Sci USA 89: 2252-2256.

Chen JW, Murphy TL, Willingham MC, Pastan I, August JT (1985) Identification of two lysosomal membrane glycoproteins. J Cell Biol 101:85-95.

Cole GM, Huynh TV, Saitoh T (1989) Evidence for lysosomal process- ing of amyloid beta-protein precursor in cultured cells. Neurochem Res 14:933-939.

Cosson P, Letourneur F (1994) Coatomer interaction with di-lysine endoplasmic reticulum retention motifs. Science 263:1629-1631.

Dyrks T, Dyrks E, Monning U, Urmoneit B, Turner J, Beyreuther K (1993) Generation of beta A4 from the amyloid protein precursor and fragments thereof. FEBS Lett 335:89-93.

Esch FS, Keim PS, Beattie EC, Blacher RW, Culwell AR, Oltersdorf T, McClure D, Ward PJ (1990) Cleavage of amyloid $\beta$ peptide during constitutive processing of its precursor. Science 248:1122-1124.

Evan GI, Lewis GK, Ramsay G, Bishop JM (1985) Isolation of monoclonal antibodies specific for human c-myc proto-oncogene product. Mol Cell Biol 5:3610-3616.

Glenner GG, Wong CW (1984) Alzheimer's disease: initial report of the purification and characterization of a novel cerebrovascular amyloid protein. Biochem Biophys Res Commun 120:885-890.

Golde TE, Estus S, Younkin LH, Selkoe DJ, Younkin SG (1992) Processing of the amyloid protein precursor to potentially amyloidogenic derivatives. Science 255:728-730.

Görlich D, Rapoport TA (1993) Protein translocation into proteoliposomes reconstituted from purified components of the endoplasmic reticulum membrane. Cell 75:615-630.

Guarnieri FG, Arterburn LM, Penno MB, Cha Y, August JT (1993) 
The motif Tyr-X-X-hydrophobic residue mediates lysosomal membrane targeting of lysosome-associated membrane protein 1. J Biol Chem 268:1941-1946.

Haass C, Selkoe DJ (1993) Cellular processing of beta-amyloid precursor protein and the genesis of amyloid beta-peptide. Cell 75:1039-1042

Haass C, Koo EH, Mellon A, Hung AY, Selkoe DJ (1992a) Targeting of cell-surface beta-amyloid precursor protein to lysosomes: alternative processing into amyloid-bearing fragments. Nature 357:500-503.

Haass C, Schlossmacher MG, Hung AY, Vigo-Pelfrey C, Mellon A, Ostaszewski BL, Lieberburg I, Koo EH, Schenk D, Teplow DB, Selkoe DJ (1992b) Amyloid beta-peptide is produced by cultured cells during normal metabolism. Nature 359:322-325.

Haass C, Hung AY, Schlossmacher MG, Oltersdorf T, Teplow DB, Selkoe DJ (1993) $\beta$-Amyloid peptide and a $3 \mathrm{kDa}$ fragment are derived by distinct cellular mechanisms. J Biol Chem 268:3021-3024.

Hilbich C, Monning U, Grund C, Masters CL, Beyreuther K (1993) Amyloid-like properties of peptides flanking the epitope of amyloid precursor protein-specific monoclonal antibody 22C11. J Biol Chem 268:26571-26577.

Höning S, Griffith J, Geuze HJ, Hunziker W (1996) The tyrosine-based lysosomal targeting signal in lamp-1 mediates sorting into Golgiderived clathrin-coated vesicles. EMBO J 15:5230-5239.

Ida N, Hartmann T, Pantel J, Schröder J, Zerfass R, Förstl H, Sandbrink R, Masters CL, Beyreuther K (1996) Analysis of heterogenous beta-A4 peptides in human cerebrospinal fluid and blood by newly developed sensitive Western blot assay. J Biol Chem 271:22908-22914.

Johnson KF, Kornfeld S (1992) A His-Leu-Leu sequence near the carboxyl terminus of the cytoplasmic domain of the cation-dependent mannose 6-phosphate receptor is necessary for the lysosomal enzyme sorting function. J Biol Chem 267:17110-17115.

Kang J, Lemaire HG, Unterbeck A, Salbaum JM, Masters CL, Grzeschik KH, Multhaup G, Beyreuther K, Mueller-Hill B (1987) The precursor of Alzheimer's disease amyloid A4 protein resembles a cell-surface receptor. Nature 325:733-736.

Kim KS, Miller DL, Sapienza VJ, Chen C-MJ, Bai C, Grundke-Iqbal I, Currie JR, Wisniewski HM (1988) Production and characterization of monoclonal antibodies reactive to synthetic cerebrovascular amyloid peptide. Neurosci Res Commun 2:121-130.

Klumperman J, Hille A, Veenendaal T, Oorschot V, Stoorvogel W, von Figura K, Geuze HJ (1993) Differences in the endosomal distributions of the two mannose 6-phosphate receptors. J Cell Biol 121:997-1010.

Koo EH, Squazzo SL (1994) Evidence that production and release of amyloid beta-protein involves the endocytic pathway. J Biol Chem 269:17386-17389.

Koo EH, Squazzo SL, Selkoe DJ, Koo CH (1996) Trafficking of cellsurface amyloid beta-protein precursor. 1. Secretion, endocytosis, and recycling as detected by labeled monoclonal antibody. J Cell Sci 109:991-998.

Kornfeld S (1992) Structure and function of the mannose 6-phosphate/ insulin-like growth factor II receptors. Annu Rev Biochem 61:307-330.

Masters CL, Simms G, Weinman NA, Multhaup G, McDonald BL, Beyreuther K (1985) Amyloid plaque core protein in Alzheimer disease and Down syndrome. Proc Natl Acad Sci USA 82:4245-4249.

Meresse S, Hoflack B (1993) Phosphorylation of the cation-independent mannose 6-phosphate receptor is closely associated with its exit from the trans-Golgi network. J Cell Biol 120:67-75.
Pohlmann R, Nagel G, Schmidt B, Stein M, Lorkowski G, Krentler C, Cully J, Meyer HE, Grzeschik KH, Mersmann G, Hasilik A, von Figura K (1987) Cloning of a cDNA encoding the human cationdependent mannose 6-phosphate-specific receptor. Proc Natl Acad Sci USA 84:5575-5579.

Ponnambalam S, Rabouille C, Luzio JP, Nilsson T, Warren G (1994) The TGN38 glycoprotein contains two non-overlapping signals that mediate localization to the trans-Golgi network. J Cell Biol 125:253-268.

Ponnambalam S, Girotti M, Yaspo M-L, Owen CW, Perry ACF, Suganuma T, Nilsson T, Fried M, Banting G, Warren G (1996) Primate homologues of rat TGN38: primary structure, expression and functional implications. J Cell Sci 109:675-685.

Reaves B, Horn M, Banting G (1993) TGN38/41 recycles between the cell surface and the TGN: brefeldin A affects its rate of return to the TGN. Mol Biol Cell 4:93-105.

Rohrer J, Schweizer A, Johnson KF, Kornfeld S (1995) A determinant in the cytoplasmic tail of the cation-dependent mannose 6-phosphate receptor prevents trafficking to lysosomes. J Cell Biol 130:1297-1306.

Ross RA, Spengler BA, Biedler JL (1983) Coordinate morphological and biochemical interconversion of human neuroblastoma cells. J Natl Cancer Inst 71:741-747.

Sambamurti K, Shioi J, Anderson JP, Pappolla MA, Robakis NK (1992) Evidence for intracellular cleavage of the Alzheimer's amyloid precursor in PC12 cells. J Neurosci Res 33:319-329.

Schagger H, von Jagow G (1987) Tricine-sodium dodecyl sulfatepolyacrylamide gel electrophoresis for the separation of proteins in the range from 1 to $100 \mathrm{kDa}$. Anal Biochem 166:368-379.

Shoji M, Golde TE, Ghiso J, Cheung TT, Estus S, Shaffer LM, Cai XD, McKay DM, Tintner R, Frangione B, Younkin SG (1992) Production of the Alzheimer amyloid beta protein by normal proteolytic processing. Science 258:126-129.

Siman R, Mistretta S, Durkin JT, Savage MJ, Loh T, Trusko S, Scott RW (1993) Processing of the beta-amyloid precursor. Multiple proteases generate and degrade potentially amyloidogenic fragments. J Biol Chem 268:16602-16609.

Simons M, Ikonen E, Tienari PJ, Cidarregui A, Monning U, Beyreuther K, Dotti CG (1995) Intracellular routing of human amyloid protein precursor: axonal delivery followed by transport to the dendrites. J Neurosci Res 41:121-128.

Simons M, De Strooper B, Multhaup G, Tienari PJ, Dotti CG, Beyreuther K (1996) Amyloidogenic processing of the human amyloid precursor protein in primary cultures of rat hippocampal neurons. J Neurosci 16:899-908.

Sisodia SS (1992) Beta-amyloid precursor protein cleavage by a membrane-bound protease. Proc Natl Acad Sci USA 89:6075-6079.

Usami M, Yamao-Harigaya W, Maruyama K (1993) The triplet of lysine residues (Lys724-Lys725-Lys726) of Alzheimer's amyloid precursor protein plays an important role in membrane anchorage and processing. J Neurochem 61:239-246.

Weidemann A, Konig G, Bunke D, Fischer P, Salbaum JM, Masters CL, Beyreuther K (1989) Identification, biogenesis, and localization of precursors of Alzheimer's disease A4 amyloid protein. Cell 57:115-126.

Yamazaki T, Koo EH, Selkoe DJ (1996) Trafficking of cell-surface amyloid beta-protein precursor. 2. Endocytosis, recycling, and lysosomal targeting detected by immunolocalization. J Cell Sci 109:999-1008. 